\title{
Cancer prevalence, inpatient mortality and its predictors after pericardiocentesis
}

\section{Perikardiyosentez \\ yapıllmış \\ hastalarda \\ kanser prevalansı, hastane içi mortalite ve mortalite prediktörleri}

\author{
İdris Buğra Çerikk, Ferhat Dindaş, Emin Koyun, İlbrahim Güil
}

Sivas Cumhuriyet Üniversitesi, Tıp Fakültesi, Kardiyoloji Anabilim Dalı, Sivas, Türkiye

Corresponding author: İdris Buğra Çerik, MD, Sivas Cumhuriyet Üniversitesi, Tıp Fakültesi, Kardiyoloji Anabilim Dalı, Sivas, Türkiye

E-mail: cerikbugra@gmail.com

Received/Accepted: August 20, 2020 /September 18, 2020

Conflict of interest: There is not a conflict of interest.

\section{SUMMARY}

Objective: Pericardiocentesis is a percutaneous drainage procedure performed in cardiac tamponade or a moderate-large pericardial effusion that does not respond to medical treatment. The prognosis varies according to the etiology of pericardial effusion, and the parameters that can determine the prognosis are unknown.

In this study, we aimed to find predictors that can determine inpatient mortality in patients who underwent pericardiocentesis and to determine cancer etiology.

Method: Ninety-one patients who underwent pericardiocentesis due to moderate-large pericardial effusion or pericardial tamponade were evaluated retrospectively. Baseline characteristics of the patients, their cancer diagnosis before and after pericardiocentesis, pericardial effusion cytology, echocardiographic parameters and laboratory parameters in the baseline evaluation were evaluated. The group with inpatient death $(n=14)$ and the surviving group $(\mathrm{n}=77)$ were compared with each other.

Results: There was no significant difference between baseline demographic characteristics and echocardiographic parameters when the patients with inpatient mortality and survivors were compared; only patients diagnosed with cancer $(p<0.001)$ and patients with malignant cytology $(p=0.041)$ were statistically significantly higher in the group with inpatient mortality. When patients with inpatient mortality and survivors were compared in terms of laboratory parameters, aspartate aminotransferase (AST) [55 (27455), 26 (19-45); $\mathrm{p}=0.007$, respectively], lactate dehydrogenase (LDH) [527 (438-944), 282 (225-381); p <0.001, respectively], C-reactive protein (CRP) [120.5 (19.8-140.7), 36.5 (8.26-86.15); $\mathrm{p}=0.016$, respectively], NTproBNP [8964 (7780-9432), 1310 (351-4556); $\mathrm{p}=0.049$ ] values were significantly higher in the inpatient mortality group than in the surviving group. The presence of cancer $(\mathrm{p}=0.001)$, AST $(\mathrm{p}=0.008)$, alanine aminotransferase (ALT) $(p=0.013)$, LDH $(p=0.015)$, CRP $(p=0.046)$ parameters were detected to be predictors that can be used to predict inpatient mortality in the univariate logistic regression analysis conducted to determine the predictors that could indicate inpatient mortality.

Conclusions: Inpatient mortality is high in patients that were detected to have underlying malignancy and pericardial involvement after pericardiocentesis. In the initial evaluation of these patients, simple laboratory tests such as AST, ALT, NTproBNP, LDH, CRP can give an idea about the short-term prognosis of the disease.

Keywords: Pericardiocentesis, cancer, mortality
İdris Buğra Çerik
(D) Ferhat Dindaş
(D) Emin Koyun
(D) İbrahim Gül

ORCID IDs of the authors:

İ.B.Ç. 0000-0003-1419-3950

F.D. 0000-0003-0053-9594

E.K. 0000-0001-9823-1613

İ.G. 0000-0003-1007-0961 
ÖZET

Amaç: Perikardiyosentez, kardiyak tamponad veya medikal tedaviye yanıt vermeyen orta-ciddi perikardiyal efüzyonda uygulanan perkütan drenaj işlemidir. Prognoz, perikardiyal efüzyon etiyolojisine göre değişiklik gösterir ve prognozu belirleyebilecek parametreler bilinmemektedir.

Bu çalışmada, perikardiyosentez uygulanan hastalarda hastane içi ölüm oranını belirleyebilecek prediktörler bulmayı ve etiyolojide kanserin yerini belirlemeyi amaçladık.

Yöntem: Orta-ciddi perikardiyal efüzyon veya perikardiyal tamponad nedeniyle perikardiyosentez uygulanan 91 hasta retrospektif olarak değerlendirildi. Hastaların temel demografik özellikleri, perikardiyosentez öncesi ve sonrası kanser tanıları, perikardiyal efüzyon sitolojileri, ekokardiyografik parametreler ve başlangıç değerlendirmesindeki laboratuvar parametreleri değerlendirildi. Hastane içi ölüm olan grup $(n=14)$ ile hayatta kalan grup $(n=77)$ birbirleriyle karşılaştırıldı.

Bulgular: Hastane içi mortalitesi olan hastalar ve sağ kalanlar karşılaştıııldığında, başlangıç demografik özellikleri ile ekokardiyografik parametreler arasında anlamlı bir fark yoktu; sadece kanser tanısı alan hastalar ( $<0.001$ ) ve malign sitolojisi olan hastalar $(\mathrm{p}=0.041)$, hastane içi mortalite olan grupta istatistiksel olarak anlamlı derecede yüksek bulundu. Hastane içi mortalite grubu ve hayatta kalan grup laboratuar parametreleri açısından karşılaştırıldığında, aspartat aminotransferaz (AST) [sırasıyla, 55 (27-455), 26 (19-45); $\mathrm{p}=0$ 0.007], laktat dehidrojenaz (LDH) [sirasiyla, 527 (438944), 282 (225-381); p <0.001], C-reaktif protein (CRP) [sirasiyla 120.5 (19.8-140.7), 36.5 (8.26-86.15); p = 0.016], NTproBNP [sırasıyla, 8964 (7780-9432), 1310 (351-4556); $\mathrm{p}=0.049$ ] değerleri hastane içi mortalite grubunda hayatta kalan gruba göre anlamlı olarak daha yüksekti. Hastane içi ölümleri gösterebilecek prediktörleri belirlemek için tek değişkenli lojistik regresyon analizi kullanıldı. Kanser varlığı $(\mathrm{p}=0,001)$, AST ( $\mathrm{p}=0,008)$, alanin aminotransferaz (ALT) $(p=0,013), \operatorname{LDH}(p=0,015), \operatorname{CRP}(p=0,046)$ parametreleri hastane içi mortaliteyi değerlendirebilen belirleyiciler olarak tespit edildi.

Sonuç: Perikardiyosentez sonrası altta yatan malignite ve perikardiyal tutulum saptanan hastalarda hastane içi mortalite yüksektir. Bu hastaların ilk değerlendirmesinde AST, ALT, NTproBNP, LDH, CRP gibi basit laboratuar testleri hastalığın kısa dönem seyri hakkında fikir verebilir.

Anahtar sözcükler: Perikardiyosentez, kanser, mortalite

\section{INTRODUCTION}

Pericardiocentesis is the drainage process from the pericardial sac in patients with pericardial tamponade, moderate-large pericardial effusion that does not respond to medical treatment and suspected bacterial or malignant etiology ${ }^{1}$. Pericarditis, tuberculosis, iatrogenic, trauma, cancer, inflammatory diseases, aortic dissection, uremia, and postmyocardial infarction are included in the etiology of large pericardial effusion and cardiac tamponade[1]. It has been stated in population-based studies that the etiology shows regional differences ${ }^{2}$. Although it differs according to etiology, with publications reporting 30-day mortality between $8 \%$ and $18 \%,{ }^{3-6}$ three-month survival has been reported to be between $18 \%$ and $90 \%$ especially in cancer patients by type of cancer ${ }^{7}$.

Commonly found in cancer patients, pericardial effusion (PE) has been reported in up to $21 \%$ of patients with underlying malignancy ${ }^{8}$ and has been shown to affect patient survival ${ }^{7,9}$.

In addition, effusive constrictive pericarditis may progress with signs and symptoms of right heart failure $^{10}$. It has been reported that mortality increases in pericardial effusions associated with heart failure ${ }^{11}$.
Biochemical parameters associated with cancer or heart failure may indicate mortality in patients with pericardial effusion and pericardial tamponade. However, there is no well-defined predictor for determining inpatient mortality in patients undergoing pericardiocentesis. In this study, we aimed to determine the etiology in our region and to find parameters that can indicate inpatient mortality in patients who underwent pericardiocentesis.

\section{MATERIAL AND METHODS}

A retrospective study was conducted between the dates of 2012 and 2019 for patients undergoing pericardiocentesis in our university hospital.

Approval from the ethics committee of the local university was obtained. The procedures used in this study adhere to the tenets of the Declaration of Helsinki. Upon approval by the ethics committee, verbally informed consent was obtained from the patients or their relatives by telephone contact.

Pericardiocentesis was performed using a $6 \mathrm{~F}$ sheath with a fluoroscopic-guided Seldinger method in a total of 91 patients due to moderatelarge pericardial effusion or pericardial tamponade within the specified study period. Percutaneous pericardiocentesis was performed through the subxiphoid or intercostal space, if appropriate. PE 
recurrence and subsequent management were reviewed and patients who underwent pericardiocentesis or surgical drainage due to recurrence were recorded. It was planned to exclude the patients who underwent surgical drainage at first admission to hospital and those who failed the procedure from the study.

The electronic medical record of each patient was reviewed to obtain baseline demographic and clinical data. The past diagnoses of the patients and their subsequent diagnoses were examined using the electronic medical record.

Laboratory examinations of all patients at the time of admission were recorded, and cytopathology and microbiology examinations from the pericardial fluid were also recorded. The effusion was classified as "malignant" if pericardial fluid cytology demonstrated malignant, suspicious, or atypical cells. However, if these features were not present in pericardial effusion cytology, they were classified as "benign".

Arterial hypertension was considered in patients with repeated blood pressure measurements of $>140 / 90 \mathrm{~mm} \mathrm{Hg}$ or those who were currently using antihypertensive drugs. Diabetes mellitus was defined as having a fasting plasma glucose level $\geq 126 \mathrm{mg} / \mathrm{dL}$ on several measurements or current use of antidiabetic medications. Coronary artery disease (CAD) was considered in patients who previously underwent revascularization by surgery or percutaneous coronary intervention. Atrial fibrillation (AF) was considered in patients who were previously diagnosed or presented with $\mathrm{AF}$ on admission.

Transthoracic echocardiography (TTE) was performed on all patients with Vivid E7 (GE Vingmed Ultrasound) echocardiography device and MS5 (1.5-4.5 MHz) ultrasound probe before or after pericardiocentesis.

Peripheral venous blood samples of the patients were obtained on their admission to the inpatient ward. Automated blood cell counter (Beckman, California) was used for measuring complete blood count parameters. Blood biochemistry parameters were measured in terms of CRP, troponin, creatinine, liver transaminases and serum electrolytes.

Baseline demographics, echocardiographic and laboratory parameters of patients with and without inpatient death were compared.

\section{Statistical Analysis}

In all statistical analyses SPSS 22.0 Statistical Package Program for Windows (SPSS Inc.,
Chicago, IL,USA) was used. In order to test normality of distribution Kolmogorov-Smirnov test was used. The continuous variables as median (quartiles), the categorical variables as percentage were expressed. In order to test the difference of the continuous variables between the groups Mann Whitney $U$ test was used. In order to test the difference of the categorical variables between the groups, Chi-square test was used. Univariate logistic regression analysis was performed to determine the predictors of inpatient mortality. A p value of $<0.05$ was accepted as statistically significant.

\section{RESULTS}

Pericardiocentesis was performed on 91 patients between the specified dates; all patients underwent fluoroscopy-guided procedures, and there were no failed drainage procedures. No periprocedural complications were reported. Inpatient mortality occurred in $14(15.3 \%)$ of the patients who presented with moderate-large pericardial effusion or tamponade and underwent pericardiocentesis. There was no important difference between baseline demographics and echocardiographic parameters when patients with inpatient mortality and survivors were compared; only patients diagnosed with cancer $(\mathrm{p}<0.001)$ and patients with malignant cytology $(p=0.041)$ were statistically significantly higher in the group with inpatient mortality (Table 1).

Pericardiocentesis procedure of three patients was performed with hemodynamic disorder. Pericardiocentesis was performed for the second time in three patients due to recurrent pericardial effusion. These patients were not diagnosed with cancer.

When examined in terms of cancer diagnosis and pericardial fluid cytology of patients who underwent pericardiocentesis, 7 patients were diagnosed with cancer after positive cytology was detected; cancer was not detected in 4 patients despite positive cytology; 6 patients were later diagnosed with cancer although negative cytology was detected; 1 patient was diagnosed with active cancer and the cytology was found to be positive; cytology from pericardial fluid from other patients with known cancer was not studied. A patient without cytological study was diagnosed with colon cancer 4 years after admission due to pericardial effusion.

The most common cancer detected in patients was lung cancer, followed by breast cancer and other cancers (Table 2). 
Table 1: Comparison of baseline characteristics and echocardiography parameters of patients with inhospital mortality and surviving

\begin{tabular}{|l|c|c|r|}
\hline Variables & $\begin{array}{c}\text { In hospital mortality } \\
(\mathrm{n}=14)\end{array}$ & $\begin{array}{c}\text { Surviving patients } \\
(\mathrm{n}=77)\end{array}$ & $p$ value \\
\hline Age $($ years $)$ & $63(55-72)$ & $70(59-81)$ & 0.167 \\
\hline Gender-Female $\mathrm{n}(\%)$ & $4(28.6)$ & $40(51.9)$ & 0.107 \\
\hline DM n(\%) & $1(7.1)$ & $20(26)$ & 0.124 \\
\hline HT n(\%) & $4(28.6)$ & $32(41.6)$ & 0.361 \\
\hline CAD n(\%) & $2(14.3)$ & $9(11.7)$ & 0.784 \\
\hline AF $\mathrm{n}(\%)$ & $1(7.1)$ & $8(10.4)$ & 0.708 \\
\hline Cancer $\mathrm{n}(\%)$ & $9(64.3)$ & $15(19.5)$ & $<\mathbf{0 . 0 0 1}$ \\
\hline Malignant cytology $\mathrm{n}(\%)$ & $4(66.7)$ & $8(24.2)$ & $\mathbf{0 . 0 4 1}$ \\
\hline EF $(\%)$ & $55(53-55)$ & $55(55-56)$ & 0.483 \\
\hline LA $(\mathrm{cm})$ & $3.5(3.3-4.1)$ & $3.7(3.4-4.2)$ & 0.386 \\
\hline IVS $(\mathrm{cm})$ & $0.9(0.9-1)$ & $1(0.9-1.1)$ & 0.073 \\
\hline LVEDD $(\mathrm{cm})$ & $4.4(4.2-4.5)$ & $4.5(4.3-4.6)$ & 0.455 \\
\hline sPAP $(\mathrm{mmHg})$ & $36(25-51)$ & $39(33-50)$ & 0.405 \\
\hline
\end{tabular}

DM: Diabetes mellitus, HT: Hypertension, CAD: Coronary artery disease, AF: Atrial fibrillation, EF: Ejection fraction, LA: Left atrium diameter, IVS: Interventricular septum diameter, LVEDD: Left ventricular end diastolic diameter, sPAP: Systolic pulmonary arterial pressure

Table 2: Cancers detected in patients undergoing pericardiocentesis

\begin{tabular}{|l|c|}
\hline Lung CA & $13(\% 54)$ \\
\hline Breast CA & $3(\% 13)$ \\
\hline Mesothelioma & $2(\% 9)$ \\
\hline Gastric CA & $2(\% 8)$ \\
\hline Colonic CA & $1(\% 4)$ \\
\hline Bladder CA & $1(\% 4)$ \\
\hline Soft tissue CA & $1(\% 4)$ \\
\hline Renal cell CA & $1(\% 4)$ \\
\hline
\end{tabular}

\section{CA: Cancer}

When the two groups were compared in terms of baseline laboratory tests, red blood cell (RBC) was significantly lower in the group that developed inpatient mortality than in the surviving group [3.72 (3.13-4.81), 4.26 (3.98-4.92); $\mathrm{p}=0.030$, respectively]. Aspartate aminotransferase (AST) was significantly higher in the inpatient mortality group than in the surviving group [55 (27-455), 26 $(19-45) ; \mathrm{p}=0.007$, respectively]. Lactate dehydrogenase (LDH) was significantly higher in the inpatient mortality group than in the survivor group [527 (438-944), 282 (225-381); p <0.001, respectively]. C-reactive protein (CRP) was found to be significantly higher in the group with inpatient mortality compared to the surviving group [120.5 (19.8-140.7), 36.5 (8.26-86.15); $\mathrm{p}=$ 0.016 , respectively]. NTproBNP value was significantly higher in the inpatient mortality group than in the surviving group [8964 (7780-9432), 1310 (351-4556); $\mathrm{p}=0.049]$. The comparison of the two groups in terms of baseline laboratory tests is shown in detail in Table 3 .

The presence of cancer $(\mathrm{p}=0.001)$, AST $(\mathrm{p}=$ $0.008)$, alanine aminotransferase (ALT) $(\mathrm{p}=$ $0.013)$, LDH $(\mathrm{p}=0.015)$, CRP $(\mathrm{p}=0.046))$ parameters were detected to be predictors that can be used to predict inpatient mortality in the univariate logistic regression analysis conducted to determine the predictors that could indicate inpatient mortality (Table 4). 
Table 3: Comparison of initial laboratory parameters of patients with in-hospital mortality and surviving

\begin{tabular}{|l|c|c|r|}
\hline Variables & $\begin{array}{c}\text { In hospital death } \\
(\mathrm{n}=14)\end{array}$ & $\begin{array}{c}\text { Surviving patients } \\
(\mathrm{n}=77)\end{array}$ & $p$ value \\
\hline RBC $\left(10^{6} / \mathrm{uL}\right)$ & $3.72(3.13-4.81)$ & $4.26(3.98-4.92)$ & $\mathbf{0 . 0 3 0}$ \\
\hline WBC $\left(10^{3} / \mathrm{uL}\right)$ & $12.64(5.88-16.80)$ & $8.34(6.46-11.39)$ & 0.143 \\
\hline HB $(\mathrm{g} / \mathrm{dL})$ & $10.9(9.25-14.3)$ & $12.5(11.1-13.3)$ & 0.121 \\
\hline Creatinin $(\mathrm{mg} / \mathrm{dL})$ & $1.01(0.81-1.35)$ & $0.92(0.74-1.19)$ & 0.341 \\
\hline eGFR $\left(\mathrm{ml} / \mathrm{min} / \mathrm{m}^{2}\right)$ & $79(48-90)$ & $72(50-90)$ & 0.921 \\
\hline Glucose $(\mathrm{mg} / \mathrm{dL})$ & $95(87-102)$ & $102(90-111)$ & 0.171 \\
\hline AST $(\mathrm{U} / \mathrm{L})$ & $55(27-455)$ & $26(19-45)$ & $\mathbf{0 . 0 0 7}$ \\
\hline ALT $(\mathrm{U} / \mathrm{L})$ & $75(13-669)$ & $24(13-41)$ & 0.059 \\
\hline Total cholesterol & $120(95-159)$ & $129(106-158)$ & 0.541 \\
\hline LDL $(\mathrm{mg} / \mathrm{dL})$ & $73(55-93)$ & $84(64-104)$ & 0.273 \\
\hline HDL $(\mathrm{mg} / \mathrm{dL})$ & $25(16-42)$ & $34(28-44)$ & 0.153 \\
\hline Total protein $(\mathrm{g} / \mathrm{dL})$ & $5.57(5.10-17.85)$ & $6.31(5.69-6.95)$ & 0.358 \\
\hline Albumin $(\mathrm{g} / \mathrm{dL})$ & $3.30(2.74-9.6)$ & $3.58(3.11-4.09)$ & 0.644 \\
\hline Uric acid $(\mathrm{mg} / \mathrm{dL})$ & $7.6(5.32-9.2)$ & $6.6(5.1-8.05)$ & 0.371 \\
\hline LDH $(\mathrm{U} / \mathrm{L})$ & $527(438-944)$ & $282(225-381)$ & $<\mathbf{0 . 0 0 1}$ \\
\hline CRP $(\mathrm{mg} / \mathrm{L})$ & $120.5(19.8-140.7)$ & $36.5(8.26-86.15)$ & $\mathbf{0 . 0 1 6}$ \\
\hline Sedimentation & $20(7-51)$ & $38(22-62)$ & 0.096 \\
\hline Troponin $(\mathrm{ng} / \mathrm{mL})$ & $0.04(0.01-1.72)$ & $0.028(0.006-0.18)$ & 0.308 \\
\hline D-dimer $(\mathrm{ng} / \mathrm{mL})$ & $2944(757-6938)$ & $1036(494-2375)$ & 0.110 \\
\hline NTproBNP $(\mathrm{pg} / \mathrm{mL})$ & $8964(7780-9432)$ & $1310(351-4556)$ & $\mathbf{0 . 0 4 9}$ \\
\hline
\end{tabular}

RBC: Red blood cell, WBC: White blood cell, HB: Hemoglobin, eGFR: Estimated glomerular filtration rate, AST: Aspartate aminotransferase, ALT: Alanin aminotransferase, LDL: Low density lipoprotein, HDL: High density lipoprotein, LDH: Lactate dehidrogenase, CRP: C-reactive protein

Table 4: Univariate regression analysis to determine in-hospital mortality

\begin{tabular}{lcccc} 
Variables & B & S.E. & $\operatorname{Exp}(\mathrm{B})$ & p value \\
\hline NT-proBNP & 0.000 & 0.000 & 1.000 & 0.083 \\
Malignant cytology & -1.833 & 0.957 & 0.160 & 0.055 \\
Cancer & -2.007 & 0.628 & 0.134 & $\mathbf{0 . 0 0 1}$ \\
AST & 0.002 & 0.001 & 1.002 & $\mathbf{0 . 0 0 8}$ \\
ALT & 0.003 & 0.001 & 1.003 & $\mathbf{0 . 0 1 3}$ \\
LDH & 0.002 & 0.001 & 1.002 & $\mathbf{0 . 0 0 5}$ \\
CRP & 0.006 & 0.003 & 1.006 & $\mathbf{0 . 0 4 6}$ \\
\hline
\end{tabular}

RBC: Red blood cell, AST: Aspartate aminotransferase, ALT: Alanin aminotransferase, LDH: Lactate dehidrogenase,

CRP: C-reactive protein

\section{DISCUSSION}

The main results of our study are that moderatelarge pericardial effusion and pericardial tamponade are associated with a high rate of inpatient mortality. Inpatient mortality was higher in patients with cancer and those with malignant cytology. When evaluated in terms of laboratory parameters, markers such as RBC, AST, ALT, NTproBNP, CRP, and LDH show statistically significant differences in the group with inpatient mortality compared to the group that did not develop inpatient mortality. In the regression analysis, we showed that, of these markers, AST, ALT, LDH and CRP could be used as predictors of mortality.
In the etiology of pericardial effusion and cardiac tamponade, there are many conditions such as idiopathic pericarditis, tuberculosis, invasive procedure complications, trauma, cancer, inflammatory diseases, aortic dissection, uremia and postmyocardial infarction, and these show regional differences ${ }^{2}$. Our region shows similar characteristics to the literature in terms of cancer prevalence detected in patients who underwent pericardiocentesis. In our study, cancer was diagnosed in $24(26 \%)$ patients; this rate was reported between 25.3-31.5\% in large-scale cohort studies $^{12,2,6}$. In addition, lung cancer is the most common malignancy (54\%) in our region, it has been reported between $44-52.9 \%$ in the literature ${ }^{12,2,6}$. In parallel with other studies evaluating inpatient mortality, it was found higher 
in cancer patients in our study also ${ }^{6,12}$. Recently, pericardial effusion and tamponade due to tuberculosis have not been reported in developed countries, nor were they detected in the patient population we evaluated. Although the number of patients we could evaluate was not high, information about common etiologies will enable more cost-effective diagnostic investigations to be made.

Cytological examination of pericardial effusion is performed to diagnose tumoral involvement of the pericardium ${ }^{13}$ and provides important information for demonstrating underlying disease, assessing prognosis, and managing treatment ${ }^{14}$. In our study, approximately $43 \%$ of the patients underwent cytological examination and according to these cytology results, 7 patients were diagnosed with new cancer. A patient without cytological study was diagnosed with colon cancer 4 years after admission due to pericardial effusion. In our study, there was a significant difference between the inpatient mortality group and the surviving group in terms of malignant cytology. Since its predictive power on prognosis has been shown in previous studies and new cancer can be diagnosed according to cytology results, it is recommended by some authors to perform cytological examination in all patients except for those with a clear cause such as iatrogenic pericardial effusions ${ }^{2}$. When our results are evaluated, it seems rational to make cytological evaluation in all patients who have undergone pericardiocentesis.

Cardiac tamponade is a condition in which the filling functions of the heart are impaired due to pericardial effusion, and clinical findings such as dyspnea, tachycardia, and hypotension can mimic heart failure ${ }^{15}$. Natriuretic peptides, on the other hand, are a well-defined marker of heart failure, which increases when the volume or pressure load of the heart increases ${ }^{16}$. While the BNP levels were not high in large pericardial effusion and cardiac tamponade due to decreased stretching of the ventricles, they were shown to increase after the drainage of pericardial effusion ${ }^{15}$. The NT-proBNP values evaluated in our study are the values obtained from the samples taken at the hospital admission of the patients, which suggests that a high NT-proBNP level may be a marker for inpatient mortality, independent of the tamponadeinduced heart failure clinic. However, in the univariate regression analysis, the difference lost its statistical significance. Repeated measurements of natriuretic peptides will better reflect developing heart failure, but their prognostic significance is uncertain and may be subject to different studies.
AST and ALT are aminotransferase enzymes that increase in intrahepatic and extrahepatic conditions. They can be elevated in conditions like congestive heart failure, hypotensive shock, ischemic hepatitis, and they have been known for a long time to increase due to pericardial effusion ${ }^{17}$. In our study, a significant relationship was found between high AST and ALT parameters and inpatient mortality. This elevation can be explained by hepatic congestion caused by impaired right ventricular filling in the acute period, but it is seen that inpatient mortality is higher in these patients despite successful drainage of pericardial effusion.

CRP is a well-defined predictor of mortality. In a meta-analysis published by $\mathrm{Li}$ et al., elevated hsCRP levels were shown to independently predict risk of all-cause, cardiovascular mortality in the general population ${ }^{18}$. Similarly, in our study, it was found to be a predictor of inpatient mortality in those who underwent pericardiocentesis.

Lactate dehydrogenase is a pro-tumor marker associated with many cancers. LDH has been shown to be an important and independent predictor of survival in many types of cancer, especially lung cancer ${ }^{19,20}$, and breast cancer ${ }^{21}$. The most common cancers found in our study in patients undergoing pericardiocentesis are also lung and breast cancer. The power of our study is not sufficient to show that LDH is an inpatient mortality predictor independent of cancer in patients who have undergone pericardiocentesis. We think that the prognostic significance of LDH in patients without an underlying cancer diagnosis and undergoing pericardiocentesis should be evaluated with different studies.

\section{Limitations}

There are several limitations in our study. Firstly, considering the small number of patients enrolled in the study, it may not be sufficient to assess the global frequency of etiology. Second, due to the retrospective design of our study, there are mostly missing data on parameters such as serous or hemorrhagic fluid characteristics, transudate or exudate differentiation, the amount of total pericardial fluid drained in the evaluation of the character of pericardial effusion, and information on these parameters could not be provided in our study. Since autopsy is not routinely performed in our region, the rate of periprocedural complications may be underestimated in patients who died in the early period. 


\section{CONCLUSION}

Significant pericardial effusion requiring pericardiocentesis is a life-threatening condition with high inpatient mortality. Inpatient mortality is found to be high in patients with underlying malignancy and pericardial involvement. Simple laboratory tests such as AST, ALT, NTproBNP, LDH, CRP that can be used in the baseline evaluation of these patients can provide very important information to clinicians about the shortterm prognosis of the disease.

\section{REFERENCES}

1. Adler $\mathrm{Y}$, Charron $\mathrm{P}$, Imazio $\mathrm{M}$, Badano L, Barón-Esquivias $\mathrm{G}$, Bogaert $\mathrm{J}$, Brucato $\mathrm{A}$, Gueret $\mathrm{P}$, Klingel $\mathrm{K}$, Lionis $\mathrm{C}$, Maisch B, Mayosi B, Pavie A, Ristic AD, Sabaté Tenas M, Seferovic P, Swedberg K, Tomkowski W (2015) 2015 ESC Guidelines for the diagnosis and management of pericardial diseases: The Task Force for the Diagnosis and Management of Pericardial Diseases of the European Society of Cardiology (ESC)Endorsed by: The European Association for Cardio-Thoracic Surgery (EACTS). Eur Heart J 36 (42):29212964. doi:10.1093/eurheartj/ehv318

2. Strobbe A, Adriaenssens T, Bennett J, Dubois $\mathrm{C}$, Desmet $\mathrm{W}$, McCutcheon K, Van Cleemput J, Sinnaeve PR (2017) Etiology and Long-Term Outcome of Patients Undergoing Pericardiocentesis. J Am Heart Assoc 6 (12). doi:10.1161/jaha.117.007598

3. Louw VJ, Reuter H, Smedema JP, Katjitae I, Burgess LJ, Doubell AF (2002) Clinical experience with pericardiocentesis and extended drainage in a population with a high prevalence of HIV. Neth Heart J 10 (10):399406

4. Saltzman AJ, Paz YE, Rene AG, Green P, Hassanin A, Argenziano MG, Rabbani L, Dangas G (2012) Comparison of surgical pericardial drainage with percutaneous catheter drainage for pericardial effusion. J Invasive Cardiol 24 (11):590-593

5. Vayre F, Lardoux H, Pezzano M, Bourdarias JP, Dubourg O (2000) Subxiphoid pericardiocentesis guided by contrast twodimensional echocardiography in cardiac tamponade: experience of 110 consecutive patients. Eur J Echocardiogr 1 (1):66-71. doi:10.1053/euje.1999.0003

6. Sethi A, Singbal Y, Kodumuri V, Prasad V (2018) Inpatient mortality and its predictors after pericardiocentesis: An analysis from the
Nationwide Inpatient Sample 2009-2013. J Interv Cardiol $31 \quad$ (6):815-825. doi:10.1111/joic.12563

7. Kim SH, Kwak MH, Park S, Kim HJ, Lee HS, Kim MS, Lee JM, Zo JI, Ro JS, Lee JS (2010) Clinical characteristics of malignant pericardial effusion associated with recurrence and survival. Cancer Res Treat 42 (4):210-216. doi:10.4143/crt.2010.42.4.210

8. Jama GM, Scarci M, Bowden J, Marciniak SJ (2014) Palliative treatment for symptomatic malignant pericardial effusion $\dagger$. Interact Cardiovasc Thorac Surg 19 (6):1019-1026. doi:10.1093/icvts/ivu267

9. Tsang TS, Seward JB, Barnes ME, Bailey KR, Sinak LJ, Urban LH, Hayes SN (2000) Outcomes of primary and secondary treatment of pericardial effusion in patients with malignancy. Mayo Clin Proc 75 (3):248-253. doi:10.4065/75.3.248

10. Imazio M, Adler $Y$ (2013) Management of pericardial effusion. Eur Heart J 34 (16):11861197. doi:10.1093/eurheartj/ehs372

11. Fröhlich GM, Keller P, Schmid F, Wolfrum M, Osranek M, Falk C, Noll G, Enseleit F, Reinthaler M, Meier P, Lüscher TF, Ruschitzka F, Tanner FC (2013) Haemodynamically irrelevant pericardial effusion is associated with increased mortality in patients with chronic heart failure. Eur Heart J 34 (19):1414-1423. doi:10.1093/eurheartj/eht006

12. Gad MM, Elgendy IY, Mahmoud AN, Elbadawi A, Tanavin T, Denktas A, Jimenez E, Kapadia SR, Jneid H (2020) Temporal trends, outcomes, and predictors of mortality after pericardiocentesis in the United States. Catheter $\begin{array}{llll}\text { Cardiovasc Interv } 95 \text { (3):375-386. } & \end{array}$ doi:10.1002/ccd.28588

13. Burazor I, Imazio M, Markel G, Adler Y (2013) Malignant pericardial effusion. Cardiology 124 (4):224-232. doi:10.1159/000348559

14. Meyers DG, Meyers RE, Prendergast TW (1997) The usefulness of diagnostic tests on pericardial fluid. Chest 111 (5):1213-1221. doi:10.1378/chest.111.5.1213

15. Minai K, Komukai K, Arase S, Nagoshi T, Matsuo S, Ogawa K, Kayama Y, Inada K, Tanigawa S, Takemoto T, Sekiyama H, Date T, Ogawa T, Taniguchi I, Yoshimura M (2013) Cardiac tamponade as an independent condition affecting the relationship between the plasma Btype natriuretic peptide levels and cardiac 
function. Heart Vessels 28 (4):510-513. doi:10.1007/s00380-012-0278-x

16. Mizuno Y, Yoshimura M, Harada E, Nakayama M, Sakamoto T, Shimasaki Y, Ogawa H, Kugiyama K, Saito Y, Nakao K, Yasue H (2000) Plasma levels of A- and B-type natriuretic peptides in patients with hypertrophic cardiomyopathy or idiopathic dilated cardiomyopathy. Am J Cardiol 86 (9):1036-1040, a1011. doi:10.1016/s00029149(00)01147-4

17. Brereton WF, Sherlock P, Cameron DJ (1965) PERICARDIAL EFFUSION. MARKED SERUM TRANSAMINASE ELEVATIONS: A REPORT OF FOUR CASES. Arch Intern Med 115:311-314. doi:10.1001/archinte.1965.03860150055010

18. Li Y, Zhong X, Cheng G, Zhao C, Zhang L, Hong Y, Wan Q, He R, Wang Z (2017) Hs-CRP and all-cause, cardiovascular, and cancer mortality risk: A meta-analysis. Atherosclerosis 259:75-82.

doi:10.1016/j.atherosclerosis.2017.02.003
19. Zhang X, Guo M, Fan J, Lv Z, Huang Q, Han J, Wu F, Hu G, Xu J, Jin Y (2016) Prognostic significance of serum LDH in small cell lung cancer: A systematic review with metaanalysis. Cancer Biomark 16 (3):415-423. doi:10.3233/cbm-160580

20. Deng T, Zhang J, Meng Y, Zhou Y, Li W (2018) Higher pretreatment lactate dehydrogenase concentration predicts worse overall survival in patients with lung cancer. Medicine (Baltimore) 97

(38):e12524. doi:10.1097/md.0000000000012524

21. Said NM (2019) Three gold indicators for breast cancer prognosis: a case-control study with ROC analysis for novel ratios related to $\mathrm{CBC}$ with (ALP and LDH). Mol Biol Rep 46 (2):2013-2027. doi:10.1007/s11033-01904650-9 